\title{
ANALISIS PENGARUH SELEBRITIS SPOKEPERSON TERHADAP EVALUASI KONSUMEN PADA IKLAN IM3 PT. INDOSAT TBK
}

\author{
Gunarso Wiwoho \\ email: gunarsowiwoho@yahoo.co.id
}

\begin{abstract}
The study analyzes the influence of celebrity spokespersons (attractiveness, trustworthiness, and expertise) toward consumer evaluation on the advertisementof IM3 starring by Asmirandah. It takes the public sample of cell phone users who've seen the advertising of IM3 starring by Asmirandah and there are some 100 people arriving in the Kebumen district. The sample techniques that used in this study is non-probability sampling using convenience sampling method. The used Instruments in this study is a questionnaire to obtain needed primary data.The main results of this study shows a significant effect together with celebrity spokespersons (attractiveness, trustworthiness, and expertise) toward the consumer evaluation. The variables of Celebrity spokespersons that have significantly effect to consumers partially toward the consumers evaluation on the advertisement of IM3, starring by Asmirandah is attractiveness and trustworthiness, whereas the expertise variable has no significant effect to consumer evaluation on the advertisement of IM3 starring by asmirandah.
\end{abstract}

Keywords: celebrity spokespersons, atrractiveness, trustworthiness, expertise and consumer evaluations.

\section{Abstraksi}

Penelitian ini bertujuan untuk menganalisis pengaruh dari celebrity spokesperson (attractiveness, trustworthiness, dan expertise) terhadap evaluasi konsumen pada iklan IM3 yang dibintangi oleh Asmirandah.

Penelitian ini mengambil sampel masyarakat umum pengguna telepon seluler yang pernah melihat iklan IM3 dengan bintang iklan Asmirandah dan berada di Kecamatan Kebumen sejumlah 100 orang. Teknik sampel yang digunakan dalam penelitian ini adalah non probability sampling dengan menggunakan metode convenience sampling. Instrumen yang digunakan dalam penelitian ini adalah kuesioner untuk memperoleh data-data primer yang dibutuhkan.

Hasil utama penelitian ini menunjukkan pengaruh yang signifikan secara bersama-sama dari celebrity spokesperson (attractiveness, trustworthiness, dan expertise) terhadap evaluasi konsumen. Variabel-variabel celebrity spokesperson yang berpengaruh signifikan secara parsial terhadap evaluasi konsumen pada iklan IM3 yang dibintangi Asmirandah adalah attractiveness dan trustworthiness. sedangkan variabel expertise tidak berpengaruh signifikan terhadap evaluasi konsumen pada iklan IM3 yang dibintangi Asmirandah.

Kata kunci : celebrity spokesperson, attractiveness, trustworthiness, expertise, dan evaluasi konsumen. 


\section{PENDAHULUAN}

Komunikasi pemasaran mempakan suatu kegiatan pertukaran informasi dua arah antara pihak-pihak atau lembaga-lembaga yang terlibat dalam pemasaran (Dharmesta, 2002: 234). Pertukaran dua arch ini kadangkadang disebut sebagai dialog pemasaran, atau secara luas komunikasi pemasaran dapat didefinisikan sebagai kegiatan komunikasi yang dilakukan oleh pembeli dan penjual, dan mempakan kegiatan yang membantu dalam pengambilan keputusan di bidang pemasaran serta mengarahkan pertukaran agar lebih memuaskan dengan cara menyadarkan semua pihak untuk berbuat lebih baik.

Semua pihak yang terlibat dalam proses komunikasi pemasaran melakukan cara yang sama, yaitu mendengarkan, bereaksi, dan berbicara hingga tercipta hubungan pertukaran yang memuaskan. Pertukaran informasi, penjelasan-penjelasan yang bersifat membujuk, dan negosiasi merupakan seluruh bagian dari proses tersebut. Komunikasi pemasaran dapat membantu mempertemukan pembeli dan penjual bersama-sama dalam suatu hubungan pertukaran; menciptakan arus informasi antara pembeli dan penjual yang membuat kegiatan pertukaran lebih efisien; dan memungkinkan semua pihak untuk mencapai persetujuan pertukaran yang memuaskan. Salah satu bagian dari proses komunikasi pemasaran adalah promosi. Promosi memainkan perm penting dalam menempatkan posisi produk di mata dan benak konsumen. Promosi memberitahukan, mengingatkan, dan membujuk pembeli serta pihak lain yang berpengaruh dalam proses pembelian. Promotional mix didefinisikan sebagai "kombinasi strategi yang paling baik dari variabel-variabel periklanan, personal selling, promosi penjualan, hubungan masyarakat dan alat promosi yang lain yang kesemuanya direncanakan untuk mencapai tujuan program penjualan".

Dari sekian banyak alat promosi tersebut, periklanan merupakan suatu kegiatan yang sangat berperan dalam menunjang keberhasilan pemasaran sebuah produk oleh perusahaan. Oleh karena itu, seiring dengan perkembangan dunia modern saat ini seorang pengiklan hams mampu memenangkan persaingan dengan menyuguhkan sebuah iklan yang efektif dan kreatif. Beberapa fungsi iklan menurut Dharmmesta (2002: 246) adalah:

1. Iklan yang baik mampu memberikan informasi mengenai produk yang ditawarkan kepada konsumen.

2. Iklan yang baik harus mampu membujuk terutama kepada pembeli-pembeli potensial, dengan menyatakan bahwa suatu produk adalah lebih baik daripada produk yang lain.

3. Sebuah iklan harus bisa menciptakan sebuah image tentang apa yang diiklankan. Hal itu bisa dicapai dengan menggunakan warna, ilustrasi, bentuk, endorser, dan layout yang menarik.

4. Sebuah iklan harus bisa memuaskan keinginan dengan cara mengarahkan konsumen untuk membeli produk tersebut sehingga kebutuhannya terpenuhi.

Kesuksesan sebuah iklan tidak hanya tergantung dari konsep yang canggih namun juga tidak terlepas dari bintang iklannya. Banyak produk yang sangat populer dan mampu mendongkrak penjualan berkat pemilihan bintang iklan yang tepat. Bahkan sebuah produk tidak jarang melekat pads figur sang bintang. Oleh karena itu, banyak pemasar memilih mempromosikan produknya melalui dunia hiburan baik musik maupun film. Pengiklan pun memasukkan unsur hiburan seperti penggunaan selebriti dan alur cerita yang menghibur. Penggunaan selebriti 
sebagai spokesperson untuk pemsahaan terns menjadi berlangsung dan menjadi iklan yang populer. Lebih dari 10 persen televisi yang mengiklankan melibatkan selebritis spokesperson (Sherman, 1985, dalam Ohanian, 1991: 46). Masan dibalik ketenaran iklan selebritis adalah kepercayaan pemasang iklan bahwa pesan yang dikirimkan oleh kepribadian selebritis mencapai suatu derajat perhatian dan daya ingat yang tinggi untuk beberapa konsumen. Ada beberapa hal yang membuat selebriti menjadi pendukung yang efektif untuk suatu produk tertentu antara lain: hubungan yang berarti atau kecocokan antara selebriti, masyarakat, dan produk itu sendiri (Shimp, 2003: 464).

Penelitian atas kredibilitas pengiklan menunjukkan bahwa pada setiap situasi, pengiklan yang dirasakan kredibel lebih efektif dibanding pengiklan yang kurang kredibel. Tetapi faktor apakah yang mendasari kredibilitas pengiklan? Apakah seorang pengiklan yang terpercaya dan efektif adalah seorang yang terkenal, menarik, terpercaya, ahli, atau bahkan kombinasi dari beberapa atau semua dari ciri ini? Apakah sebaiknya pengiklan terpercaya adalah seorang yang dinamis, berkualitas, dan berwibawa? Literatur mengidentifikasikan tiga dimensi sebagai komponen kredibilitas pengiklan yaitu: attractiveness, trustworthiness, dan expertise (Ohanian, 1991: 46).

\section{KAJIAN PUSTAKA}

\section{Komunikasi Pemasaran}

Komunikasi pemasaran merupakan suatu kegiatan komunikasi yang dilakukan oleh pembeli dan penjual, dan merupakan kegiatan yang membantu dalam pengambilan keputusan di bidang pemasaran serta mengarahkan pertukaran agar lebih memuaskan dengan cara menyadarkan semua pihak untuk berbuat lebih baik (Gharmesta, 2002: 234).

Komunikasi pemasaran adalah istilah yang digunakan untuk menggambarkan aliran informasi tentang produk dari pemasar kepada konsumen. Pemasar menggunakan iklan, pemasaran langsung, publisitas, promosi penjualan, dan penjualan langsung untuk memberikan informasi yang mereka harapkan akan mempengaruhi keputusan pembelian konsumen. Sebaliknya, konsumen memanfaatkan komunikasi pemasaran selama proses pembelian untuk mengumpulkan informasi tentang atribut dan manfaat dari produk (Wells dan Prensky,1996: 427).

\section{Proses Komunikasi Pemasaran}

Inti dari komunikasi pemasaran adalah komunikasi itu sendiri yang berarti pengiriman pesan dari sumber melalui media kepada penerima. Menurut Wells dan Prensky (1996: 427) ada beberapa elemen yang perlu diperhatikan dalam proses komunikasi, yaitu:

1. Sumber (source), yaitu pihak yang mengawali komunikasi, dalam komunikasi pemasaran yang menjadi pengirim adalah pemasar. Supaya dapat menyampaikan informasi yang mudah diakses, pemasar mengkodekan (encoding) informasi menjadi pesan yang akan diberikan kepada konsumen.

2. Pesan (message), adalah isi informasi yang disampaikan pengirim (pemasar) kepada penerima (konsumen).

3. Media (medium), adalah saluran komunikasi yang digunakan oleh pengirim untuk menyampaikan pesan kepada penerima.

4. Penerima (receiver), adalah target dari pesan, dalam hal ini konsumen yang pemasar inginkan untuk diberikan informasi. Ketika pesan sudah diterima 
oleh konsumen, pesan hares diterjemahkan. Penguraian pesan (decoding) adalah proses interpretasi yang dilakukan konsumen untuk memahami pesan yang disampaikan oleh pemasar.

5. Gangguan (noise), yaitu distorsi yang dapat mengganggu jalannya proses komunikasi atau pesan-pesan acak dan bertentangan yang dapat mengganggu komunikasi yang diharapkan.

6. Umpan Balik (Feedback), yaitu umpan balik yang dilakukan penerima pesan kepada pengirim pesan.

\section{Promosi}

Promosi merupakan anus informasi atau persuasi satu arch yang dibuat untuk mengarahkan seseorang atau organisasi kepada tindakan yang menciptakan pertukaran dalam pemasaran. Jadi, promosi merupakan salah satu aspek yang penting dalam manajemen pemasaran dan sering dikatakan sebagai "proses berlanjut". Ini disebabkan karena promosi dapat menimbulkan rangkaian kegiatan selanjutnya dari perusahaan.Dalam kegiatan promosi dikenal istilah promotional mix yang didefinisikan sebagai kombinasi strategi yang paling baik dari variabel-variabel periklanan, personal selling, dan alat promosi yang lain, yang kesemuanya direncanakan untuk mencapai tujuan program penjualan.

\section{Periklanan}

Periklanan adalah komunikasi non individu dengan sejumlah biaya, melalui berbagai media yang dilakukan oleh perusahaan, lembaga non-laba, serta individuindividu.

Secara umum, periklanan dihargai karena dikenal sebagai pelaksana beragam fungsi komunikasi yang penting bagi perusahaan bisnis dan organisasi lainnya
(Shimp, 2003: 357). Fungsi-fungsi tersebut antara lain:

\section{Informing}

Periklanan membuat konsumen sadar akan merek-merek baru, mendidik mereka tentang berbagai fitur dan manfaat merek, serta memfasilitasi penciptaan citra merek yang positif. Karena merupakan suatu bentuk komunikasi yang efektif, berkemampuan menjangkau khalayak luas dengan biaya per kontrak yang relatif rendah, periklanan memfasilitasi pengenalan merek-merek barn, meningkatkan jumlah permintaan terhadap merek-merek yang telah ada, dan meningkatkan puncak kesadaran dalam benak konsumen untuk merek-merek yang sudah ada dalam kategori produk yang matang. Periklanan menampilkan peran informasi bernilai lainnya, baik untuk merek yang diiklankan maupun konsumennya dengan mengajarkan manfaat-manfaat baru dari merek-merek yang telah ada.

\section{Persuading}

Periklanan yang efektif akan mampu membujuk pelanggan untuk mencoba produk dan jasa yang diiklankan. Terkadang persuasi berbentuk mempengaruhi permintaan primeryakni, menciptakan permintaan bagi keseluruhan kategori produk. Lebih sering, iklan berupaya untuk membangun permintaan sekunder, yaitu permintaan bagi merek perusahaan secara spesifik.

\section{Reminding}

Iklan menjaga agar merek perusahaan tetap segar dalam ingatan para konsumen. Periklanan yang efektif juga meningkatkan minat konsumen terhadap merek yang sudah ada dan pembelian sebuah merek yang mungkin tidak akan dipilihnya. Periklanan lebih jauh didemonstrasikan untuk mempengaruhi pengalihan merek (brand swictching) dengan mengingatkan para konsumen yang akhir-akhir ini belum 
membeli suatu merek yang tersedia dan mengandung atribut-atribut yang menguntungkan.

\section{Adding Value}

Periklanan membeli nilai tambah pada merek dengan mempengaruhi persepsi konsumen. Periklanan yang efektif menyebabkan merek dipandang sebagai lebih elegan, lebih bergaya, lebih bergengsi, dan bisa lebih unggul dari tawaran pesaing.

\section{Kerangka Penelitian}

Berdasarkan perumusan masalah yang digunakan dalam penelitian ini, dapat dibuat bagan kerangka pemikiran hubungan antar variabel penelitian yang terdapat pada gambar berikut:

\section{Gambar 1}

Kerangka Penelitian

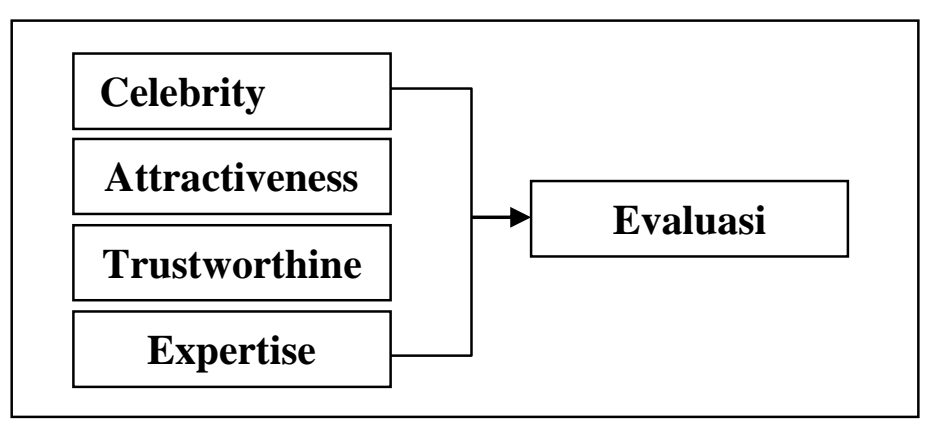

Hipotesis

Suatu hipotesis merupakan pernyataan adanya suatu hubungan tertentu antara variabel-variabel yang digunakan, sifatnya adalah sementara dan ini berarti bahwa suatu hipotesis dapat diubah atau diganti dengan hipotesis lain yang lebih tepat. Tujuan suatu hipotesis adalah untuk memberi arch pads penelitian dan membatasi variabel-variabel yang digunakan. Pengujian hipotesis dapat juga menunjukkan hubungan sebab akibat antara beberapa variabel (Koentjaraningrat, 1990: 28). Berdasarkan keterangan tersebut, serta landasan teori dan kerangka pemikiran, maka hipotesis yang dapat dirumuskan dalam penelitian adalah :
H1. Attractiveness dari Celebrity Spokesperson secara parsial berpengaruh signifikan terhadap evaluasi konsumen.
H2. Trustworthiness dari Celebrity Spokesperson secara parsial berpengaruh signifikan terhadap evaluasi konsumen.

H3. Expertise dari Celebrity Spokesperson secara parsial berpengaruh signifikan terhadap evaluasi konsumen.

H4. Celebrity Spokesperson yang terdiri dari Attractiveness, Trustwrthiness, dan Expertise, secara simultan berpengaruh signifikan terhadap evaluasi konsumen.

\section{METODE PENELITIAN}

\section{Populasi dan Sampel}

\section{Populasi}

Populasi merupakan keseluruhan grup baik orang kejadian ataupun sesuatu yang menarik peneliti untuk melakukan penelitian terhadapnya (Sekaran, 2000: 266). Populasi dalam penelitian ini adalah seluruh masyarakat umum pengguna telepon seluler yang pernah menyaksikan iklan IM3 yang dibintangi oleh Asmirandah dan berada di Kecamatan Kebumen. Unit analisis adalah satuan-satuan atau individuindividu yang hendak diteliti (Sekaran, 2000: 266). Unit analisis dalam penelitian adalah individuindividu.

\section{Sampel}

Teknik sampel yang digunakan adalah non probability sampling dengan menggunakan metode convenience sampling. Pada metode non probability sampling tidak semua unsur dalam populasi mempunyai kesempatan yang sama untuk menjadi sampel penelitian. Convenience sampling adalah mengumpulkan informasi dari anggota populasi yang mudah didapatkan. Penelitian ini menggunakan convenience sampling 
karena pertimbangan kemudahan untuk memperoleh data serta tidak memakan banyak waktu dan biaya (Sekaran, 2000: 281). Sampel dalam penelitian ini adalah 100 orang dari masyarakat umum pengguna telepon seluler yang pernah menyaksikan iklan IM3 yang dibintangi oleh Asmirandah dan berada di Kebumen.

\section{Variabel Penelitian}

\section{Attractiveness}

Attractiveness merupakan penampilan fisik dari celebrity spokesperson, yang ditampilkan oleh pengiklan agar mendapat tanggapan dari audiens. Kebanyakan televisi dan iklan cetak menggunakan orang-orang yang secara fisik adalah menarik. Penampilan fisik yang menarik berfungsi sebagai isyarat yang memudahkan atau memodifikasi pengolahan informasi dengan mengarahkan perhatian konsumen ke stimuli pemasaran yang relevan. Riset menunjukkan bahwa komunikator yang menarik secara fisik menjadi sukses dalam mengubah kepercayaan dibanding dengan komunikator yang kurang menarik. Dengan kata lain, suatu iklan dengan seorang yang cantik merupakan suatu keunggulan yang lebih baik (Shimp, 2003: 468). Attractiveness dalam penelitian ini diukur dengan menggunakan 4 buah pertanyaan.

\section{Trustworthiness}

Trustworthiness mengacu kepada kejujuran, integritas, dan dapat dipercayainya seorang spokesperson (Shimp, 2003: 470). Sedangkan menurut Ohanian (1991: 46), Trustworthiness merupakan kepercayaan konsumen terhadap pengiklan dalam memberikan informasi yang obyektif dan jujur. Dalam suatu iklan, penggunaan selebritis yang terpercaya akan lebih efektif dalam mempengaruhi audiens. Trustworthiness dalam penelitian ini diukur dengan menggunakan 3 buah pertanyaan.

\section{Expertise}

Menurut Shimp (2003: 470) expertise mengacu pada pengetahuan, pengalaman atau ketrampilan yang dimiliki seorang spokesperson yang berhubungan dengan topik iklannya. Menurut Ohanian (1991: 46), Expertise merupakan tingkat dimana seorang komunikator dirasa menjadi sumber dari pernyataan yang sah. Expertise merupakan salah satu faktor yang mendukung dari kredibilitas mengenai pengetahuan seorang komunikator terhadap produk yang diiklankan, sehingga akan berdampak positif pads perubahan sikap audiens. Expertise dalam penelitian ini diukur dengan menggunakan 4 buah pertanyaan.

\section{Evaluasi Konsumen}

Gagasan dari evaluasi konsumen terbentuk dari sikap dan minat responden pads tiga level yang berbeda dari hierarchy of effects. Responden diberi pertanyaan untuk menunjukkan tingkat dimana mereka yakin bahwa celebrity spokesperson pads iklan suatu produk akan mempengaruhi perhatian terhadap iklan, perasaan tertarik terhadap produk yang ditawarkan, dan kesediaan untuk membeli produk yang diiklankan. Evaluasi konsumen diukur dengan 3 item pertanyaan mengenai tanggapan responden terhadap celebrity spokesperson pads iklan IM3 yang terdiri dari ketertarikan terhadap iklan, ketertarikan terhadap produk, dan minat membeli produk yang masing-masing terdiri dari 1 item pertanyaan.

\section{Uji Validitas}

Tujuan uji validitas adalah untuk mengetahui apakah suatu alat ukur benarbenar mengukur sebuah konsep yang dikehendaki dan tidak mengukur konsep yang lain (Sekaran, 2000: 207). Suatu kuesioner dikatakan valid jika pertanyaan pads kuesioner mampu untuk mengungkapkan sesuatu yang akan diukur oleh kuesioner tersebut. Jadi, validitas ingin mengukur apakah pertanyaan dalam 
kuesioner yang sudah dibuat betul-betul dapat mengukur apa yang hendak diukur. Validitas butir pertanyaan menggunakan metode Product Moment Pearson Correlation.

\section{Uji Validitas Variabel Attractiveness}

nilai signifikansi lebih kecil dari 0,05 (Sig < $0,05)$.

\section{Uji Validitas Variabel Expertise}

Tabel 3 Uji Validitas Expertise

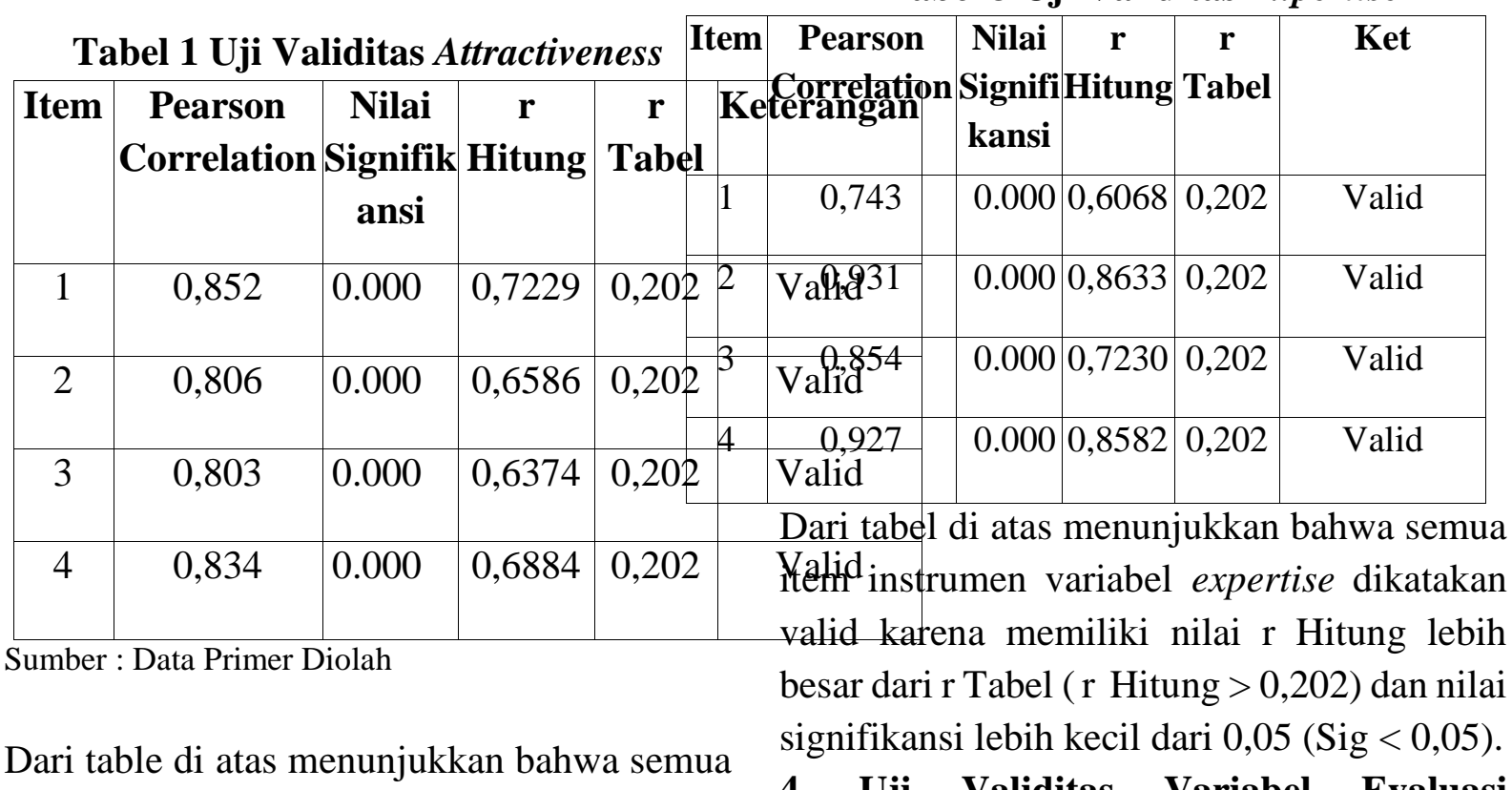

item instrumen variabel attractiveness dikatakan valid karena memiliki nilai $r$ Hitung lebih besar dari r Tabel ( $r$ Hitung > 0,202) dan nilai signifikansi lebih kecil dari 0,05 (Sig < $0,05)$.

\section{Uji Validitas Variabel Trustworthiness}

Tabel 2 Uji Validitas Trustworthiness

\begin{tabular}{|c|c|c|c|c|c|}
\hline Item & $\begin{array}{c}\text { Pearson } \\
\text { Correlati } \\
\text { on }\end{array}$ & $\begin{array}{c}\text { Nilai } \\
\text { Signifik } \\
\text { ansi }\end{array}$ & $\begin{array}{c}\text { r } \\
\text { Hitung }\end{array}$ & r Tabel & Ket \\
\hline 1 & 0,763 & 0.000 & 0,4749 & 0,202 & Valid \\
\hline 2 & 0,809 & 0.000 & 0,5625 & 0,202 & Valid \\
\hline 3 & 0,890 & 0.000 & 0,7333 & 0,202 & Valid \\
\hline
\end{tabular}

Somber : Data Primer Diolah, (2009)

Dari tabel di atas menunjukkan bahwa semua item instrumen variabel trustworthiness dikatakan valid karena memiliki nilai r Hitung lebih besar dari r Tabel (r Hitung > 0,202) dan

\section{Konsumen}

Uji Validitas Evaluasi Konsumen

\begin{tabular}{|c|c|c|c|c|c|}
\hline Item & $\begin{array}{c}\text { Pearson } \\
\text { Correlat } \\
\text { ion }\end{array}$ & $\begin{array}{c}\text { Nilai } \\
\text { Signifik } \\
\text { ansi }\end{array}$ & $\begin{array}{c}\text { r } \\
\text { Hitung }\end{array}$ & r Tabel & Ket \\
\hline 1 & 0,818 & 0.000 & 0,5613 & 0,202 & Valid \\
\hline 2 & 0,854 & 0.000 & 0,6748 & 0,202 & Valid \\
\hline 3 & 0,846 & 0.000 & 0,6526 & 0,202 & Valid \\
\hline
\end{tabular}

Dari tabel di atas men unj ukkan bahwa semua item instrumen variabel evaluasi konsumen dikatakan valid karena memiliki nilai $r$ Hitung lebih besar dari r Tabel (r Hitung > 0,202) dan nilai signifikansi lebih kecil dari 0,05 (Sig < $0,05)$.

\section{Uji Reliabilitas}

Uji reliabilitas digunakan untuk mengungkapkan stabilitas internal dari jawaban responden dalam satu variabel. Hal 
ini dilakukan untuk mengetahui sejauh mana pengukuran dapat memberikan hasil yang tidak berbeda (konsisten), jika dilakukan kembali pads subyek yang sama (Sekaran, 2000: 206). Uji reliabilitas dalam penelitian ini menggunakan skor Cronbach Alpha dengan derajat kepercayaan $95 \%$. Reliabilitas dinyatakan dengan koefisien alpha yang mempunyai rentang antara 0 sampai 1 . Semakin mendekati angka 1 berarti semakin tinggi reliabilitasnya. Secara umum, reliabilitas dengan nilai Alpha Cronbach kurang dari 0,60 dikatakan buruk, nilai Alpha Cronbach dalam range 0,60 sampai dengan 0,80 dapat diterima, dan nilai Alpha Cronbach lebih dari 0,80 dianggap baik (Sekaran, 2000: 312). Perhitungan Alpha Cronbach dilakukan dengan menggunakan SPSS versi 11.5. Tabel berikut. merangkum hasil uji reliabilitas data penelitian.

Uji Reliabilitas Penelitian

\begin{tabular}{|l|c|c|}
\hline Variabel & $\begin{array}{c}\text { Alpha } \\
\text { Cronbach }\end{array}$ & $\begin{array}{r}\text { Keterangakariabel dependen adalah variabel yang akan } \\
\text { diestimasi, biasanya menggunakan simbol Y. }\end{array}$ \\
\hline Attractiveness & 0,8420 & $\begin{array}{r}\text { Reliabel hasil uji regesi linear berganda dapat dilihat } \\
\text { pada tabel berikut berikut ini: }\end{array}$ \\
\hline Trustworthiness & 0,7554 & Reliabel \\
\hline Expertise & 0,8886 & Reliabel \\
\hline
\end{tabular}

Uji Regresi Linear Berganda

Coefficients $^{a}$

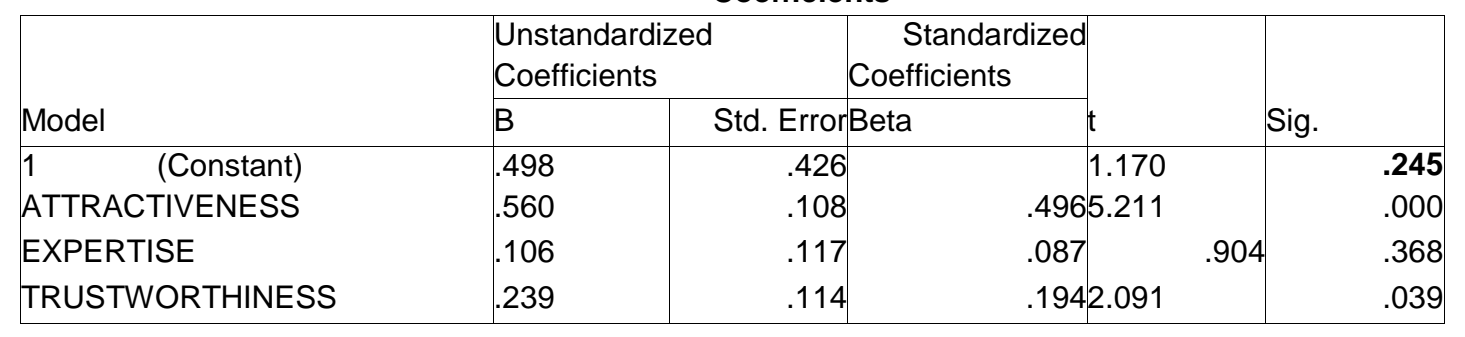

Persamaa regresi berganda sebagai berikut: $\mathrm{Y}=0,498+0,496 \cdot \mathrm{X}_{1}+0,087 \cdot \mathrm{X}_{2}+0,194 \cdot \mathrm{X}_{3}$ Sebagai interpretasi dari persamaan tersebut: 1. Konstanta sebesar 0,498 menunjukkan bahwa apabila variabel attractiveness, expertise, dan trustworthiness adalah konstan

\begin{tabular}{|l|c|c|}
\hline Evaluasi & 0,7867 & Reliabel \\
Konsumen & & \\
\hline
\end{tabular}

Dari tabel diatas Hasil uji reliabilitas variabel menunjukan bahwa seluruh komponen dalam variabel penelitian ini adalah reliabel. Hal ini didukung dengan skor alpha cronbach yang berkisar antara 0,7554 sampai dengan 0,8886. Attractiveness memiliki skor Alpha Cronbach sebesar 0,8420, trustworthiness memiliki skor Alpha Cronbach sebesar 0,7554, expertise memiliki skor Alpha Cronbach sebesar 0,8886, dan evaluasi konsumen memiliki skor Alpha Cronbach sebesar 0,7867.

\section{Uji Regresi Linear Berganda}

Uji regresi linear berganda bertujuan untuk menjelaskan pengaruh dan hubungan antara variabel-variabel independen (bebas) dan variabel dependen (terikat). Variabel independen adalah variabel yang menerangkan pengaruhnya terhadap variabel dependen, biasanya menggunakan simbol X. 
signifikansi sebesar $0,000<0,05$, berpengaruh terhadap evaluasi konsumen menunjukkan bahwa attractiveness adalah attractiveness karena mempunyai nilai mempunyai pengaruh yang positif dan koefisien regresi terbesar jika dibandingkan signifikan terhadap evaluasi konsumen.

3. Koefisien regesi variabel expertise sebesar 0,087 dengan nilai signifikansi sebesar 0,368 $>0,05$, menunjukkan bahwa expertise tidak berpengaruh signifikan terhadap evaluasi konsumen.

4. Koefisien regesi variabel trustworthiness sebesar 0,194 dengan nilai signifikansi sebesar $0,039<0,05$, menunjukkan bahwa trustworthiness mempunyai pengaruh yang positif dan signifikan terhadap evaluasi konsumen.

dengan nilai koefisien regresi variabel yang lain.

\section{Uji t Regresi Linear Berganda (t test)}

Uji-t berfungsi untuk mengetahui apakah variabel independen secara parsial mempengaruhi variabel dependen. Dalam penelitian ini uji-t digunakan untuk menguji hipotesis yaitu untuk mengetahui apakah variabel-variabel attractiveness, expertise, dan trustworthiness secara parsial mempengaruhi evaluasi konsumen. Hasil 5. Variabel yang paling dominan analisis data adalah sebagai berikut:

Uji t Regresi Linear Berganda

\begin{tabular}{|l|c|c|c|c|}
\hline \multicolumn{1}{|c|}{ Variabel } & t Hitung & t Tabel & $\begin{array}{c}\text { Nilai } \\
\text { Signifi kansi }\end{array}$ & Keterangan \\
\hline Attractiveness & 5,211 & 1,99 & 0,000 & Signifikan \\
\hline Expertise & 0,904 & 1,99 & 0,368 & $\begin{array}{c}\text { Tidak } \\
\text { :c1. }\end{array}$ \\
\hline Trustworthiness & 2,091 & 1,99 & 0,039 & Signifikan \\
\hline
\end{tabular}

Berdasarkan tabel diatas, dapat dijelaskan bahwa:

1. Attractiveness mempunyai nilai t hitung sebesar 5,211>t tabel dan nilai signifikansi sebesar $0,000<0,05$ yang berarti bahwa attractiveness berpengaruh positif dan signifikan terhadap evaluasi konsumen.

2. Expertise mempunyai nilai $\mathrm{t}$ hitung sebesar $0,904<\mathrm{t}$ tabel dan nilai signifikansi sebesar $0,368>0,05$ yang berarti bahwa expertise tidak berpengaruh signifikan terhadap evaluasi konsumen.

3. Trustworthiness mempunyai nilai thitung sebesar 2,091 > t tabel dan nilai signifikansi sebesar $0,039<0,05$ yang berarti bahwa trustworthiness berpengaruh positif dan signifikan terhadap evaluasi konsumen.

\section{Uji F Regresi Linear Berganda (F test)}

Uji $F$ digunakan untuk mengetahui apakah variabel independen secara bersama-sama atau simultan berpengaruh terhadap variabel dependen. Dan uji F dapat diketahui apakah variabel-variabel attractiveness, expertise, dan trustworthiness secara bersama-sama mempengaruhi evaluasi konsumen.

Hasil analisis data adalah sebagai berikut: 
Uji F Regresi Linear Berganda

ANOVA

\begin{tabular}{|c|c|c|c|c|c|}
\hline Model & $\begin{array}{l}\text { Sum of } \\
\text { Squares }\end{array}$ & $\mathrm{df}$ & Mean Square & $\mathrm{F}$ & Sig. \\
\hline Regression & 17.732 & 3 & 5.911 & 26.681 & $.000^{\mathrm{a}}$ \\
\hline Residual & 21.267 & 96 & .222 & & \\
\hline Total & 38.999 & 99 & & & \\
\hline
\end{tabular}

Tabel di atas menunjukkan bahwa nilai $\mathrm{F}$ hitung adalah sebesar 26,681 > F tabel sebesar 2,72 dan mempunyai nilai signifikansi sebesar $0,000<0,05$ yang berarti bahwa variabel attractiveness, expertise, dan trustworthiness secara bersama-sama berpengaruh signifikan terhadap evaluasi konsumen.

\section{Koefisien Determinasi (Adjusted R}

\section{Square)}

Nilai koefisien determinasi menunjukkan berapa besar persentase variasi dalam variabel dependen yang dapat dijelaskan oleh variasi variabel independen. Berdasarkan perhitungan uji koefisien determinasi hasil olah data SPSS 11.5, diperoleh hasil seperti pada table berikut i ni:

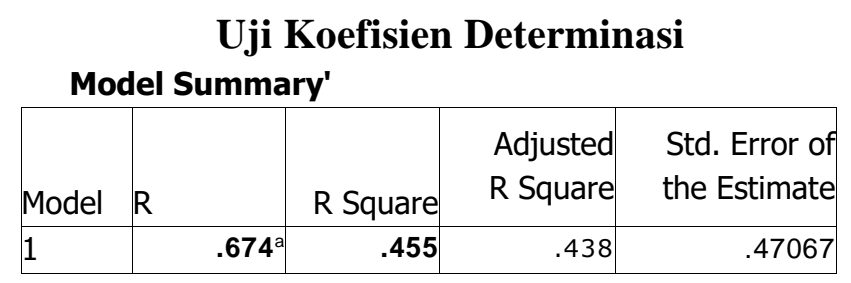

Berdasarkan tabel 4.16., besarnya nilai Adjusted $R$ square persamaan regresi linear berganda adalah sebesar sebesar 0,438 atau 43,8\%. Hal ini menunjukkan bahwa cakupan pengaruh yang dapat diterangkan oleh attractiveness, expertise, dan trustworthiness $\mathrm{sec}=$ simultan (bersama-sama) terhadap evaluasi konsumen adalah 43,8\%, sedangkan $56,2 \%$ pengaruh terhadap evaluasi konsumen diterangkan oleh variabel lain yang tidak tercakup dan tidak dijelaskan dalam penelitia ini, misalnya norma subyektif, sikap, sampel gratis,sponsorship dan lain-lain.

\section{Implikasi Manajerial}

Attractiveness dari seorang bintang iklan mengacu pads nilai sosial yang dirasakan. Biasanya berasal dari penampilan fisik bintang iklan, kepribadian, maupun status sosial. Seiring meningkatnya penggunaan selebriti sebagai pendukung produk barang dan jasa, attractiveness menjadi suatu dimensi yang penting dalam hubungannya dengan kredibilitas bintang iklan. Kebanyakan televisi dan iklan cetak menggunakan bintang iklan yang secara fisik menarik perhatian, dimana konsumen cenderung akan membentuk kesang positif tentang bintang iklan tersebut.

Trustworthiness mengacu pads kepercayaan konsumen terhadap bintang iklan dalam memberikan informasi yang obyektif dan jujur. Kebanyakan kita akan mempertimbangkan seorang teman yang terpercaya atas berbagai bal. Pada sisi lain, kadang-kadang tenaga penjualan maupun bintang iklan sering mempunyai pengetahuan yang lebih baik atas bidang tertentu dibanding seorang teman yang kurang ahli.

Expertise merupakan pengetahuan celebrity spokesperson tentang produk yang sangat mendalam, yang ditampilkan oleh pengiklan agar mendapat tanggapan dari audiens. Suatu penelitian yang menyelidiki keahlian bintang iklan dalam komunikasi persuasif yang biasanya menunjukkan bahwa keahlian bintang iklan memiliki suatu dampak positif pada perubahan sikap. Akhirnya, dalam suatu konteks penjualan, seorang tenaga penjualan yang ahli, akan membujuk pelanggan untuk

Fokus Bisnis Vo. 8, No. 1, 2019|20 
membeli suatu produk dengan jumlah lebih banyak dibandingkan dengan tenaga penjualan yang tidak ahli.

\section{Kesimpulan}

Setelah dilakukan penelitian mengenai pengaruh celebrity spokesperson terhadap evaluasi konsumen pads iklan IM3 oleh konsumen, dengan melihat basil analisis data yang dilakukan terhadap responden yang berjumlah 100 orang, maka dapat dikemukakan beberapa ksimpulan sebagai berikut:

1. Hasil penelitian menunjukkan bahwa variabel-variabel celebrity spokesperson yang meliputi attractiveness, trustworthiness, dan expertise, secara simultan berpengaruh signifikan terhadap evaluasi konsumen. Hal ini ditunjukkan dengan nilai signifikansi pada uji $\mathrm{F}$ Regrersi Linear Berganda, dimana memiliki nilai signifikansi sebesar 0,000. dan nilai $F$ hitung sebesar 26,681 lebih besar dari nilai $\mathrm{F}$ tabel sebesar 2,72.

2. Attractiveness secara parsial berpengaruh positif dan signifikan terhadap evaluasi konsumen. Hal ini ditunjukkan dengan nilai signifikansi sebesar 0,000 dan nilai $t$ hitung sebesar 5,211 lebih besar dari nilai t tabel sebesar 1,99, yang berarti bahwa attractiveness memiliki pengaruh yang postitf dan signifikan terhadap evaluasi konsumen.

3. Trustworthiness secara parsial berpengaruh positif dan signifikan terhadap evaluasi konsumen. Hal ini ditunjukkan dengan nilai signifikansi sebesar 0,039 dan nilai t hitung sebesar 2,091 lebih besar dari nilai t tabel sebesar 1,99 , yang berarti bahwa trustworthiness memiliki pengaruh yang positif dan signifikan terhadap evaluasi konsumen.

4. Expertise secara parsial tidak berpengaruh signifikan terhadap evaluasi konsumen. Hal ini ditunjukkan dengan nilai sig. 0,368 dan nilai t hitung sebesar 0,904 lebih kecil dari nilai t tabel sebesar 1,99, yang berarti bahwa expertise tidak berpengaruh signifikan terhadap evaluasi konsumen.

5. Variabel yang paling besar pengaruhnya terhadap evaluasi konsumen adalah attractiveness karena mempunyai nilai koefisien regresi sebesar 0,496 merupakan yang terbesar jika dibandingkan dengan nilai koefisien regresi variabel yang lain.

6. Nilai Adjusted R2 sebesar 0,438 menunjukkan bahwa cakupan pengaruh dari attractiveness, trustworthiness, dan expertise terhadap evaluasi konsumen adalah sebesar 0,438 atau $43,8 \%$ sedangkan sisanya yaitu $56,2 \%$ diterangkan oleh variabel-variabel lain 


\section{DAFTAR PUSTAKA}

Dharmmesta, Basu Swastha. (2002). Azas-azas Marketing. Edisi Ketiga. Yogyakarta: Liberty.

Ghozali, Imam. (2001). Aplikasi Analisis Multivariate dengan Program SPSS. Semarang: Badan Penerbit Universitas Diponegoro.

Kotler, Philip (terj). (2000). Manajemen Pemasaran Edisi Milenium. Jakarta: Prenhallindo.

Ghanian, R. (1991). The Impact of Celebrity Spokeperson 's Perceived Image On Consumer's Intention To Purchase. Journal of Advertising Research, Vol. 31, February/March, 46-54.

Pelsmacker, Patrick De, Maggie Gevens, dan Joeri Van den Bergh. (2001). Marketing Communications. New York: Prentice Hall.

Shimp, Terrence A. (2003). Advertising, Promotion, and Supplemental Aspect of Integrated Marketing Communications. 6th ed. Thomson: South-western.

Sekaran, Uma. (2000). Research Methods For Business: A Skill-Building Approach.3rd ed. New York: John Wiley \& Sons, Inc.

Wells, William D., \& David Prensky. (1996). Consumer Behavior. New York: John Wiley \& Sons, Inc. 